\title{
Acupuncture can serve at most only as supplementary therapy for myasthenia gravis
}

\author{
Josef Finsterer \\ Krankenanstalt Rudolfstiftung, Messerli Institute, Vienna, Austria \\ Correspondence to: Josef Finsterer, MD, PhD. Postfach 20, 1180 Vienna, Austria. Email: fifigs1@yahoo.de.
}

Submitted Dec 28, 2019. Accepted for publication Feb 14, 2020.

doi: 10.21037/apm.2020.04.07

View this article at: http://dx.doi.org/10.21037/apm.2020.04.07

With interest we read the article by Zhang et al. about a systematic review and meta-analysis about randomised controlled trials (RCTs) investigating the effect of acupuncture as a treatment of myasthenia gravis (MG) (1). It was concluded that acupuncture has a beneficial effect on MG as an integrative therapy (1). Acupuncture enhances the effect of medication for MG (1). The study has a number of shortcomings.

A major shortcoming of the study is that serum titres of acetyl-choline-receptor antibodies (ACRAs), antiMUSK-antibodies, LRP4-antibodies, agrin-antibodies, repetitive nerve stimulation (RNS), or the vital capacity were not taken as outcome parameters. Since MG is an immunological disease, we should know if acupuncture truly modifies the basic immunological and electrophysiological parameters.

We do not agree with the statement that "choline-esterase inhibitors, immune-suppressants, thymectomy, and plasma exchange are unable to cure MG" (1) On the contrary, in the majority of the cases MG patients respond favourably to these measures with a long-term effect. Missing in this respect are intravenous immunoglobulins (IVIGs) and plasma separation.

Concerning the inclusion criteria, we should know if also patients with congenital myasthenic syndrome (CMS) or patients negative for ACRAs but positive for MUSKantibodies, agrin or LRP4 antibodies were included. According to the method section there were no limitations in age.

We also do not agree with the statement that "drug treatments are unable to inhibit the relapse of symptoms and achieve constant remission" (1). On the contrary, the vast majority of MG patients achieves a stable course of the disease for years under the established therapeutic management. The outcome is particularly favourable for those who tightly adhere to the regimen and strictly avoid factors triggering relapses, or myasthenic or cholinergic crises.

We should know if acupuncture was more effective in MG patients receiving immunosuppressants or having undergone thymectomy than in MG patients only taking cholinesterase inhibitors.

The treatment effect in MG is much dependent on the co-medication MG patients are regularly taking. Thus, we should know which drugs the included patients were taking in addition to the anti-myasthenic medication.

Since the quality of the 13 included studies was assessed as low with an unclear or high risk of bias (1), its results have to be interpreted with caution and the conclusions drawn need to be revised.

We should know if sham acupuncture was as effective as regular acupuncture. Furthermore, it should be investigated if acupuncture has a drug-sparing effect. If $M G$ patients undergoing acupuncture as a supplementary treatment need to take lower dosages of anti-myasthenic drugs, authorities also in the Western world could be convinced to finance acupuncture as a supportive measure for MG patients.

Overall, this interesting study has a number of shortcomings which need to be addressed before final conclusions can be drawn. MG should not be treated my acupuncture alone as long as data are lacking convincingly showing that acupuncture is as effective as the currently available standard therapy for MG.

\section{Acknowledgments}

Funding: None. 


\section{Footnote}

Conflicts of Interest: The author has completed the ICMJE uniform disclosure form (available at http://dx.doi. org/10.21037/apm.2020.04.07). The author has no conflicts of interest to declare.

Ethical Statement: The author is accountable for all aspects of the work in ensuring that questions related to the accuracy or integrity of any part of the work are appropriately investigated and resolved.

Open Access Statement: This is an Open Access article distributed in accordance with the Creative Commons Attribution-NonCommercial-NoDerivs 4.0 International
License (CC BY-NC-ND 4.0), which permits the noncommercial replication and distribution of the article with the strict proviso that no changes or edits are made and the original work is properly cited (including links to both the formal publication through the relevant DOI and the license). See: https://creativecommons.org/licenses/by-nc-nd/4.0/.

\section{References}

1. Zhang X, Ding W, Wang Z, et al. The effectiveness and safety of acupuncture for the treatment of myasthenia gravis: a systematic review and metaanalysis of randomized controlled trials. Ann Palliat Med 2019;8:576-85.
Cite this article as: Finsterer J. Acupuncture can serve at most only as supplementary therapy for myasthenia gravis. Ann Palliat Med 2020;9(3):1278-1279. doi: 10.21037/apm.2020.04.07 